\title{
A REDEMOCRATIZAÇÃO BRASILEIRA SOB O POLÊMICO ENFOQUE DAS PUBLICAÇÕES DO PROJETO MEMÓRIA GLOBO
}

\author{
Redemocratization in Brazil, under the controversial approach of \\ Globo Memory Project publications
}

\begin{abstract}
Márcia Fantinatti
Jornalista, doutora em Ciências Sociais pela Universidade Federal de Campinas (Unicamp), professora da Faculdade de Jornalismo da PUC-Campinas, líder do grupo de pesquisa Comunicação e Política (CNPq) e editora-chefe da Revista Comunicarte, Campinas, SP, Brasil, e-mail: marcia_fantinatti@puc-campinas.edu.br
\end{abstract}

\section{Resumo}

A partir do levantamento da narrativa e depoimentos de profissionais ligados à Rede Globo, divulgados em livros publicados pelo Projeto Memória Globo, focalizamos de modo específico as versões contemporâneas apresentadas para episódios ocorridos no período de redemocratização no Brasil, englobando desde a fase final da ditadura militar até a eleição e o afastamento do primeiro presidente civil, no período pós-ditadura. Nosso estudo se refere particularmente à cobertura jornalística do movimento pelas "Diretas Já" (1983-1984); à polêmica edição de debate presidencial entre os candidatos Collor e Lula (1989), levada ao ar pelo Jornal Nacional às vésperas do segundo turno; e à cobertura jornalística do movimento "Fora Collor", que reivindicava o impeachment do então presidente da República Fernando Collor de Mello (do PRN - Partido da Reconstrução Nacional) (1992). Assim, realizamos pesquisa documental e análise bibliográfica, adotamos conceitos de hegemonia e de identidade cultural para a análise dos dados e procuramos revelar os principais pontos de vista que tentam justificar práticas jornalísticas pelas quais a Rede Globo foi criticada. Os resultados da pesquisa indicaram que o Projeto Memória Globo pretende promover a construção de novas identidades coletivas e busca consolidar uma nova imagem para a Rede Globo. Mostra as Organizações Globo como vetor essencial nos avanços democráticos no país. Assim, apela a um novo consenso sobre os acontecimentos históricos.

Palavras-chave: Rede Globo de Televisão. História. Jornalismo.

\begin{abstract}
Based on the narrative survey and testimonies from professionals associated with the "Rede Globo", exposed in books published by the Globo Memory Project, we focused specifically on the contemporary versions presented for
\end{abstract}


episodes that occurred during the redemocratization in Brazil, encompassing from the final phase of the military dictatorship until the election and subsequent step down of the first civil president, in the post-dictatorship era. Our study refers particularly to the journalistic coverage of the movement for the "Diretas Já" (1983-1989); the polemic edition of presidential debate between the candidates Collor and Lula (1989), broadcasted by Jornal Nacional, on the eve of the elections; to the journalistic coverage of the "Fora Collor" movement, that vindicated the impeachment of the president of the Republic at the time, Fernando Collor de Mello (of PRN - Partido da Reconstrução Nacional) (1992). Therefore, we conducted desk research and literature review, adopt the concepts of hegemony and cultural identity for the analysis and we sought to reveal the main points of view that try to justify journalistic practices that the "Rede Globo" was criticized for. The survey results indicated that the Globo Memory Project aims to promote the construction of new collective identities and intends to build a new image for the Rede Globo. It shows Globo Organizations as an essential vector in democratic advances in the country. Thus, calls for new consensus about the historical events.

Keywords: Rede Globo Network. History. Journalism.

\section{INTRODUÇÃO}

Apresentam-se, neste artigo, resultados de pesquisa acerca do discurso contemporâneo das Organizações Globo sobre a fase de redemocratização brasileira. A partir da análise das referências a esse período, produzidas sob responsabilidade do Projeto Memória Globo ${ }^{1}$, destacam-se depoimentos oficiais a respeito de episódios no campo do jornalismo que marcaram de maneira negativa a imagem da emissora de televisão: a cobertura do movimento conhecido por "Diretas já", em 1984; o apoio velado ao candidato Fernando Collor de Mello nas eleições presidenciais de 1989; e a omissão no processo de denúncias jornalísticas que colaboraram para o impeachment desse, em 1992. A 'Era Collor' talvez possa ser definida como exemplo da exacerbação da influência da TV nos rumos da política. Tanto a centralidade do meio televisivo para a eleição de Collor, quanto os caminhos, também envolvendo essa poderosa mídia, que o levaram ao afastamento da presidência da República, estão repletos de fenômenos instigantes sobre o alcance da TV na formação da opinião pública.

Os objetivos principais do presente estudo foram: identificar as noções e/ou conceitos de jornalismo presentes na argumentação a respeito das práticas jornalísticas adotadas pela Rede Globo, da fase final da ditadura militar à renúncia do primeiro presidente eleito diretamente, no pós-militar, e efetuar um balanço comparativo entre os estudos críticos em relação à atuação da emissora e o discurso contemporâneo desta.

\section{METODOLOGIA}

Efetuamos uma pesquisa documental e bibliográfica a respeito da atuação do telejornalismo da Rede Globo no período de 1984 a 1992, com atenção especial para o tratamento dado à questão da transição política (da fase final da ditadura ao período inicial da Nova República); a partir daí, detectamos quais foram as principais críticas dirigidas ao telejornalismo da emissora, no que se refere à temática das eleições presidenciais. Em seguida, procuramos destacar, das obras do Projeto Memória Globo, o discurso contemporâneo que representaria uma espécie de contra-ataque às críticas recebidas a respeito da atuação jornalística da TV Globo.

Um dos principais elementos a desvendar, dentro da temática - a programação da televisão associada a abuso de poder e manipulação de informações e o discurso promocional que procura livrá-la desse estigma -, é o particular movimento de "transformação da identidade dos media"; para usar expressão de Martín-Barbero \& Rey, que, de modo pertinente, consideram que as indústrias culturais

1 O Projeto Memória Globo, criado em março de 1999, é uma área da Central Globo de Comunicação que pesquisa a história da TV Globo e de suas produções. 
"[...] constituem hoje a mais complexa reorganização da hegemonia" (MARTÍN-BARBERO; REY, 2001, p. 100). É sobre a nova hegemonia em construção segundo a qual a Rede Globo teria praticado sempre um jornalismo isento e imparcial -, que buscamos refletir. Assim, apoiamo-nos no conceito de Hall (1980), para quem um ponto de vista hegemônico é aquele:

a) que defina, segundo seus próprios termos, o horizonte mental ou o universo de significados possíveis, de todo um setor de relações em uma sociedade ou cultura, e b) que tenha o carisma da legitimidade, que pareça em sintonia com o que é 'natural', 'inevitável' na ordem social (HALL, 1980, p. 83).

O Projeto Memória Globo procura atuar na construção das novas identidades coletivas, buscando para a emissora a consolidação de uma nova imagem. Pretende que as Organizações Globo afirmem-se como vetor essencial das conquistas e avanços democráticos no País, organizando, assim, novos consensos a seu respeito. Ao problematizarmos as motivações da Rede Globo na direção de uma mudança de imagem social perante o público, lançamos uma hipótese norteadora para a nossa reflexão: os relatos atuais sobre a redemocratização, pelo viés do Projeto Memória Globo, não colaboram para o resgate da memória coletiva sobre o fim da ditadura militar no Brasil, mas, sim, para produzir sutis distorções. Tem-se, a um só tempo, um discurso em transformação e a transfiguração da história. Instiganos refletir sobre a operação atual de 'apagamento' da memória sobre a atuação da TV sob a ditadura. Assim, respaldamos nossas análises no campo da reflexão sobre o papel das mídias em conceituações a respeito da identidade cultural. Concordamos com Hall (1997), segundo o qual no processo de formação de novas identidades participam elementos de intersecção e de negociação, ou seja, envolvem-se as identidades originais.

A retomada de fatos do passado e, também, as respectivas justificativas para a adoção de determinadas condutas e práticas jornalísticas pressupõem a 'naturalização' de conceitos de 'certo' e 'errado', perante o público leigo - que, muito provavelmente, constitui o público-alvo do Memória Globo -, tanto no que se refere à imparcialidade, quanto nos significados das múltiplas formas de interferir nos processos políticos e, ainda, nos ângulos de interpretação do que vem a ser, afinal, a democracia. Assim, para além de buscar nas obras do Projeto Memória Globo verdades ou mentiras, nosso referencial conceitual conduziu-nos a preocupações para com as maneiras pelas quais: a) a argumentação, ali presente, apropria-se do contexto político atual para fazer valer as justificativas apresentadas para os episódios do passado pelos quais foi criticada; b) aproveita-se de elementos do senso comum, das generalidades ou abstrações - a respeito tanto do que seja o papel do jornalismo, quanto do que seja a potencialidade do meio televisivo para provocar o debate social e/ ou para intervir nas decisões no terreno da política, num debate eleitoral - para dar consistência à nova imagem pretendida pelas Organizações Globo perante o público na atualidade, décadas após o fim da ditadura.

Não se pode pensar nos padrões de identidade ou de cultura que se difundem em meio ao público de maneira extensiva, generalizada, como um dado pronto ou hermético. A chamada 'memória coletiva' - de acontecimentos como os governos autoritários, guerras ou genocídios, por exemplo depende, em grande medida, de como a indústria audiovisual a eles se reporte. A cultura popular é resultado de mediações num processo que envolve trocas comunicativas, elementos de resistência e assimilação da cultura dominante (STOREY, 1993). O que equivale a afirmar que as empresas de comunicação ou o jornalismo não refletem um consenso social - do processo de hegemonia - já presente e sim participam de sua construção. Essa ideia é particularmente importante para a reflexão sobre a construção da memória do jornalismo e da redemocratização, a partir de obras do Memória Globo: figuram não simplesmente como reprodutoras, mas como agentes ativos na construção do consenso.

\section{RESULTADOS}

O "Diretas já", segundo o Projeto Memória Globo, permite reflexões sobre a censura e a autocensura. A cobertura jornalística sobre o movimento popular por eleições diretas, realizado de 1983 a 1984, tem sido retomada em diversas ocasiões, na atualidade, pela própria Rede Globo. Está na biografia de Roberto Marinho, escrita por Pedro 
Bial (BIAL, 2004, p. 286); em edições especiais de O Globo Repórter e em publicações da editora Globo, tais como a Revista Época: “[...] 'O povo não é bobo, abaixo a Rede Globo' foi o slogan mais repetido na campanha pelas eleições diretas, que comoveu o país naquele ano, mas não empolgou a rede. A Globo demorou para cobrir os comícios e foi duramente criticada pela omissão" (REVISTA ÉPOCA, 2003, p. 22-23). Já aparecera também na teledramaturgia da emissora, em minisséries (BUCCI, 1996, p. 89) e na novela Esperança, em cujo último capítulo, em fevereiro de 2003, o protagonista já velho cita acontecimentos políticos: "Ao citar o período militar, repressão, campanha pela anistia, pelas diretas já, fora Collor etc., o narrador vai incluindo-se, bem como aos seus filhos, netos, bisnetos [...]" (FANTINAT'TI, 2004, p. 303).

É no livro Jornal Nacional - Notícia Faz. História (2004), porém, que se encontram referências mais sistematizadas. Entre essa obra, publicada em 2004, e um artigo de Ali Kamel (diretor-executivo de jornalismo da Globo) divulgado em O Globo em 2003, há grande sintonia. Em ambas as publicações, no que se refere às "Diretas", argumenta-se que, contrariamente ao propalado, a Rede Globo cobriu os comícios, assim como noticiou o mais importante, realizado na Praça da Sé. Afirmações em contrário são referidas como "acusações". Sustenta-se, paralelamente, que quem critica a postura da emissora, ignora ou subestima o papel da censura e estaria, além disso, motivado pela expectativa frustrada de que ela apoiasse as "Diretas", como foi o caso do jornal $A$ Folha de S. Paulo.

Da pesquisa documental que realizamos, que envolveu o resgate do material veiculado no Jornal Nacional em 25 de janeiro de 1984, comprovase que o telejornal não omite o comício a favor das "Diretas". A chamada da matéria, ao contrário, omitia o objetivo do ato público realizado naquela data na Sé: "Festa em São Paulo. A cidade comemorou seus 430 anos com mais de 500 solenidades. A maior foi um comício na praça da Sé" (JORNAL NACIONAL, 2004, p. 157).

No livro, argumenta-se que o conteúdo da matéria não deixava dúvidas quanto à natureza do comício, pois a reportagem relatara que o objetivo do evento era pedir eleições diretas. Quanto à ausência dessa informação na chamada, é minimizada, como tendo se tratado de falha técnica e justificada pela existência de uma relação direta entre o aniversário e o comício: "A chamada da matéria [...] referia-se ao comício como um dos eventos comemorativos do aniversário da capital paulista. De fato, havia a relação entre a manifestação e o aniversário da cidade" (JORNAL NACIONAL, 2004, p. 157). Como a função da escalada é exatamente a de despertar a atenção do telespectador (KYRILLOS; FEIJÓ, 2003, p. 92) - basta sublinhar que se trata de frases de impacto, utilizadas para abrir o programa (PATERNOSTRO, 1999, p. 42) - é falha que não pode ser minimizada, sobretudo num contexto politicamente polêmico. Ademais, a escassez de informações, que o tempo reduzido dedicado ao assunto determinara - a matéria teve apenas 2 minutos e 17 segundos de duração não contribuiu senão para obscurecer e fragmentar a campanha pelas "Diretas", encoberta pela sombra do anúncio, em primeiro plano, do aniversário da capital paulista.

Sobre a ação da censura sobre o $J N$, sob a ditadura, as pressões sobre o noticiário são descritas nas obras do Projeto Memória Globo como implacáveis:

À medida que sua audiência aumentava, o Jornal Nacional era cada vez mais visado. [...] foram vetadas notícias sobre cassações de mandatos e suspensão de direitos políticos; a denúncia de acordos militares entre Brasil e EUA; a visita da Anistia Internacional... (JORNAL NACIONAL, 2004, p. 35).

Acrescenta-se que não somente o telejornal era alvo dos censores:

A censura não se limitava às notícias: interferia também nos programas de entretenimento da TV Globo. Foram inúmeros os casos de restrições à dramaturgia da emissora. $\mathrm{O}$ mais sério foi o da proibição, a dois dias da estréia, da novela 'Roque Santeiro', em agosto de 1975 (JORNAL NACIONAL, 2004, p. 77).

Da pesquisa bibliográfica, tem-se que o papel da Globo, no período final da ditadura, pode ser classificado mais propriamente como autocensura. E que isso se modifica quando outros canais passam a noticiar o "Diretas já". As emissoras Manchete e Bandeirantes deram ampla cobertura ao comício da Sé, exemplifica Conti (1999, p. 37-38), obrigando a Globo a noticiá-lo: 
Numa reunião na sala de Armando Nogueira, [Boni] determinou que uma repórter falasse da Praça da Sé, em menos de vinte segundos, que ali estava sendo comemorado com um show o aniversário de São Paulo. Não deu certo: além de omitir, a Globo foi acusada de distorcer a verdade.

Depoimento de funcionário do alto escalão da Globo confirma a autocensura, admitindo a existência de atenção redobrada com o tema "Diretas", e esclarece que a diluição da natureza do comício era desejada:

A campanha das diretas foi uma censura dupla: primeiro a censura da censura, depois a censura do doutor Roberto [Marinho]. Como a televisão é uma concessão do serviço público, eles [os militares] sempre mantinham uma pressão muito grande dentro da televisão. No momento das Diretas-Já eles ameaçaram claramente a Globo de perder a concessão ou de interferir mais duramente no entretenimento. Então, o doutor Roberto não queria que se falasse em Diretas-Já. Eu fui o emissário final do pessoal do jornalismo na conversa com doutor Roberto e ele permitiu que a gente transmitisse aquilo ali dizendo que havia um show pró-Diretas-Já, mas sem a participação de nenhum dos discursantes, quer dizer, a palavra e o que se dizia, estava censurado. (PADIGLIONE, 2005).

Segundo o livro, "[...] o anseio era que a Globo endossasse editorialmente a campanha" (Jornal Nacional, 2004, p. 158).

\section{OS IMPACTOS DA LINGUAGEM TELEVISIVA NA PRIMEIRA ELEIÇÃO PRESIDENCIAL NO PÓS-DITADURA: a edição do debate entre Collor $\times$ Lula, no segundo turno, em 1989}

Passados, então, pouco mais de cinco anos da não aprovação da Emenda Dante de Oliveira, que havia motivado a campanha por "Diretas", e, finda a ditadura militar, localiza-se um outro episódio pelo qual a Globo seria acusada de um comportamento flagrantemente parcial no tratamento da notícia. O ano de 1989 marca a realização da primeira eleição direta para presidente após o período militar. É um momento delicado da história do jornalismo da emissora, que teria realizado uma edição tendenciosa do debate entre Fernando Collor de Melo (Partido da Reconstrução Nacional) e Luiz Inácio Lula da Silva (Partido dos Trabalhadores), levada ao ar pelo JN, às vésperas do disputado segundo turno da eleição. Vinte anos depois, ainda há tentativas de justificar o apoio dado a Collor, em detrimento de Lula, haja vista a referência direta presente no recém-lançado Jornal Nacional - Modo de fazer (BONNER, 2009).

A emissora, que ao longo da campanha presidencial fora acusada de apoio ao candidato do PRN, edita um debate presidencial - realizado em clima de forte polarização política, em que as pesquisas de intenção de voto apontavam uma diferença entre os candidatos, na preferência dos eleitores, situada em torno de 5\% - favorecendo a candidatura de Collor. O tempo dedicado a mostrar a performance de Collor no debate foi maior que o utilizado para mostrar Lula. Além disso, foram mostrados trechos do debate que favoreciam o primeiro e depreciavam o segundo.

No livro JornalNacional-a notíciafaz história, a polêmica edição do debate Collor $\times$ Lula é recolocada, sob novos ângulos. João Roberto Marinho (vice-presidente das Organizações Globo) relativiza os prejuízos causados pela emissora à candidatura de Lula; ao retomar a fatídica edição do $J N$, comenta-a relacionada à edição feita no Jornal Hoje, da emissora, supostamente favorável à candidatura Lula. Por fim, exibe-se também uma outra nuance da postura de João Roberto, mais refletida, pelo passar dos anos, segundo declara. Acrescenta que o erro - presente tanto na edição do Jornal Hoje quanto na do Jornal Nacionalnão se deu por má-fé, mas por inexperiência:

[...] eu debito os dois erros à inexperiência de todos nós na época. É preciso sempre ter em mente que aquela era a primeira eleição para presidente na era da televisão de massa. Não passa pela minha cabeça que os equívocos tenham sido cometidos por má-fé. (JORNAL NACIONAL, 2004, p. 231, grifos nossos).

Fincado esse ponto de vista, que repele qualquer visão de conjunto sobre os fatos, o livro prossegue, transcrevendo uma teia sem fim de explicações dadas por jornalistas supostamente 
envolvidos. Armando Nogueira (diretor da Central Globo de Jornalismo, na ocasião) acusa Alberico de Souza Cruz (ex-diretor de telejornais da Rede), que acusa Ronald de Carvalho (editor de política), que estaria sob orientação de Alice-Maria (diretoraexecutiva), que alega ter se surpreendido ao ver a edição no ar; finalmente, Octavio Tostes (editor de texto do JN) assume ter sido o responsável pela edição do debate. Tostes afirma que a edição foi manipulada e sem preocupações com isenção (2004, p. 220). Seus superiores hierárquicos não utilizam tais termos, mas acabam confirmando as ordens de editar beneficiando Collor. Não viam mal nisso e demonstram sintonia com a lógica expressa por João Roberto Marinho, de que era necessário traduzir, na edição, a superioridade de Collor (que havia vencido o debate) sobre Lula (que havia sido muito infeliz, ido mal no debate), para ser fiel ao que de fato se deu.

A edição de debates aparece como exemplo a não ser repetido:

Hoje, a TV Globo adota como norma não editar debates; eles devem ser vistos na íntegra. Porque, ao condensá-los, necessariamente bons e maus momentos dos candidatos terão de ficar de fora, segundo a escolha de um editor ou um grupo de editores (JORNAL NACIONAL, 2004, p. 214).

No entanto, o livro e as demais fontes de informações oferecidas pelo Projeto Memória Globo, indicam a noção de que Collor venceu o debate e isso precisaria ser refletido pelo jornalismo da Globo: "Collor tinha ganhado de $3 \times 0$, e o Jornal Hoje mostrara um compacto como se a partida tivesse terminado em $3 \times 2$. OJornal Nacional teria mostrado um compacto mais próximo de $3 \times 0$ "(JORNAL NACIONAL, 2004, p. 214).

Sem hesitar, João Roberto Marinho toma sua visão pessoal dos acontecimentos como padrão de realidade:

A edição do Jornal Nacional refletiu melhor o debate, que teve um vencedor. Depois que vi no ar, gostei sem dúvida mais da edição do JN. A edição do Hoje foi uma edição com excessiva preocupação em equilibrar o que não teve equilíbrio e, portanto, fugiu do que aconteceu (JORNAL NACIONAL, 2004, p. 212).

\section{UM JORNALISMO 'MORNO' E SEM FUROS DE REPORTAGEM, NUM DOS MOMENTOS MAIS PALPITANTES DA CHAMADA "NOVA REPÚBLICA": a Globo e o "Fora Collor"}

Diferentemente dos episódios anteriores, para a fraca atuação jornalística nas denúncias contra o governo Collor, a Globo não procura apresentar a sua versão. Isso se deve, provavelmente, ao fato dessa crítica ter sido mais difusa e de menor impacto em relação às demais. E, ainda, por não se referir a algum aspecto específico de seu telejornalismo, como flagrante manipulação da informação ou autocensura, mas, sim, ao aspecto geral, que foi a omissão. A parte do livro Jornal Nacional - A notícia faz história dedicada ao processo que culminou no afastamento de Fernando Collor de Mello da presidência destaca uma entrevista exclusiva realizada pelo jornalista Roberto Cabrini com o tesoureiro da campanha, o "PC Farias", num momento em que esse, acuado por ameaças que dizia vir sofrendo, saíra de maneira ilegal do país e fora localizado pela equipe da Globo em Londres. A reportagem é contada em seus detalhes no livro vai da página 273 a 276 - e veicula uma imagem de jornalismo investigativo de primeira grandeza. No entanto, não deve passar despercebido ao leitor que ela foi levada ao ar somente num momento em que Collor já estava afastado do poder há tempos, ou seja, em setembro de 1993. Cabe registrar que as mais importantes denúncias de corrupção que envolviam, primeiro de forma indireta, e um pouco depois, diretamente o presidente da República, não partiram da Globo.

A revista Veja e a Istoé empenhavam-se, semanalmente, na descoberta de indícios que estabelecessem ligações entre os diferentes acusados e Collor; obtinham em primeira mão depoimentos de funcionários ligados ao governo, tais como motoristas, secretárias. O SBT, no qual, à época, Jô Soares comandava seu programa de entrevistas, trouxe declarações decisivas do irmão do presidente, Pedro Collor. Enquanto isso, a Globo cobria de modo discreto os desdobramentos da Comissão Parlamentar de Inquérito criada para averiguar o envolvimento de Collor em atos ilícitos. Curiosamente, uma minissérie produzida pela Globo, que esteve no ar de julho a agosto de 1992, intitulada Anos Rebeldes, cujo enredo baseava-se no movimento estudantil no Brasil na época dos "anos de chumbo", foi relacionada como 
um dos motes do movimento "Fora Collor", que recebeu também a denominação "caras-pintadas"2. Não é possível afirmar se a ficção, de fato, teve influências sobre a mobilização estudantil real. De todo modo, registre-se que, do ponto de vista do telejornalismo, a cobertura da Globo ficou aquém, ao ser comparada com o ritmo das revelações por outras fontes.

\section{ANÁLISE DOS RESULTADOS}

Aderir, endossar, apoiar, torcer, empolgarse. Era isso o que, segundo o discurso atual das Organizações Globo, esperavam da emissora os apoiadores do movimento por "Diretas"; daí se deduz que o seu jornalismo teria sido criticado em função de ter frustrado tais expectativas. No intuito de fazer parecer que foi a imparcialidade a marca da cobertura jornalística sobre as "Diretas", demonstra-se justamente o contrário. Se os depoimentos atuais, para justificar o exíguo tempo dedicado ao movimento pelas "Diretas Já" (ou os ardis na edição: mistura de assuntos, subtração de termos, omissão do assunto na chamada de uma matéria etc.), apoiam-se em expressões tais como "a Globo não fazia torcida" ou "a Globo não endossava", apenas contribuem para confirmar o que já se sabia: que quando os proprietários da emissora não concordam com uma opinião, ela não terá o devido destaque no Jornal Nacional. Sem rodeios - e, aparentemente sem perceber as contradições que esse tipo de afirmação revela - admite-se que as práticas jornalísticas foram simples desdobramentos da opinião dos chefes (refletida nos editoriais); estavam longe, portanto, de refletir o interesse público.

A respeito da polêmica edição do debate eleitoral entre Collor e Lula, em 1989, no conjunto da argumentação oferecida pelo livro não localizamos, propriamente, o reconhecimento de um erro cometido. Ao contrário: o diretor proprietário afirma convicto que, se em sua opinião Collor havia 'vencido' o debate, essa vitória deveria necessariamente se refletir na edição jornalística do telejornal de sua emissora. Sem se envergonhar em reduzir a grave questão ao simplório raciocínio de um placar esportivo.
Não é vetado ao jornalismo produzir análise, interpretação ou opinião. Mas o que chama atenção é a perspectiva adotada: a insistência em que algo que está claramente localizado no campo da opinião apareça convertido em perspectiva única. Ou seja, a defesa da noção segundo a qual recortes repletos de elementos subjetivos se deram em nome da objetividade jornalística, em nome da realidade (uma realidade unívoca, inquestionável, nesse caso), para que se fizesse supostamente o relato dos fatos tal como ocorreram, duas candidaturas são mostradas pelo telejornalismo ao eleitorado em flagrantes condições de desigualdade.

Se, por outro lado, o autor da justificativa tem consciência de que a virtual vitória de Collor no debate com Lula corresponde a mero ponto de vista ou à convicção política, situados, portanto, no terreno opinativo. A noção de jornalismo interpretativo sustentada pela emissora ancora-se em pressupostos dos sistemas políticos autoritários e não no ideário democrático.

Ao contrário, considerar que o julgamento pessoal sobre a superioridade do candidato Collor corresponde aos fatos, ao "que aconteceu" e que deveria ser refletido pelo telejornalismo da Globo, equivale a incapacidade de aceitar a alteridade, de supor que, sob outros critérios de avaliação de um candidato ou a partir de outros valores, perder ou ganhar um debate de ideias é questão para a qual se deve admitir múltiplas respostas. Sabe-se que, nem sequer num plano puramente formal ou quantitativo, das pesquisas quantitativas de intenção de voto, a emissora dispunha de elementos concretos para julgar antecipadamente se, também segundo o juízo de cada um dos eleitores, Collor havia "vencido" o debate. Não ficam claros quais os critérios adotados para considerar que não houve equilíbrio de forças, dando a entender que o jogo político foi reduzido ao jogo de cena, sob os holofotes televisivos. Mas não se pode perder de vista o fundamental: a emissora emitiu julgamento que caberia ao eleitor.

Outra concepção a respeito do jornalismo sobressai - nesse caso, diz respeito à potencialidade da linguagem televisiva em suplantar outros elementos. Em alguns depoimentos, a edição e o

\footnotetext{
2 Trata-se de movimento composto em sua maioria por estudantes, que realizavam passeatas e atos públicos em todo o país, pedindo a renúncia de Collor; muitos deles apareciam com os rostos pintados.
} 
próprio debate eleitoral são referidos de modo que não se contesta a ideia segundo a qual a performance no 'palco' televisivo seja sinônimo de capacidade para cumprir um programa de governo. No discurso corrente, sair-se bem nos 60 minutos de um debate ao vivo, acabou adquirindo importância decisiva, como se o candidato ao governo se candidatasse ao papel de ator, num programa de calouros. Como se a eficácia de uma plataforma política fosse redutível à aparição de seu representante na tela da TV. Essa concepção indicaria, segundo nos parece, o triunfo dos critérios de linguagem e enquadramento da reportagem televisiva sobre a cultura política. Essa concepção não se esgota nos produtores de jornalismo; alcança e influencia as lideranças político partidárias. Segundo registra o site do Memória Globo, representantes do PT teriam avaliado que Lula não tinha "ido bem" no debate:

O PT chegou a mover uma ação contra a emissora no Tribunal Superior Eleitoral. O partido queria que novos trechos do debate fossem apresentados no Jornal Nacional antes das eleições, como direito de resposta, mas o recurso foi negado. Em frente à sede da Rede Globo, no Rio de Janeiro, atores da própria emissora, junto com outros artistas e intelectuais, protestaram contra a edição. No entanto, a própria liderança do P'T, apesar de não admitir a derrota, reconheceu que Lula não se saíra bem no confronto com Collor (DEBATE ENTRE CANDIDATOS À PRESIDÊNCIA, 1989).

A partir de 1989, a Globo definiu, enfim, para além da ênfase numa candidatura, quais os parâmetros a serem usados para desqualificar ou eleger um chefe de Estado: a boa aparição no vídeo, a imagem associada a padrões impostos de beleza física ou bons modos de vestir-se e apresentar-se, a forma e impostação ao falar (a de Collor, supostamente mais firme), substituindo todos os complexos elementos envolvidos numa escolha do mandatário da Nação. E a assimilação passiva de tais critérios revela em que medida se está impregnado pela ótica imposta pela "era da TV": sem questionamentos ao fato de que realidade e imagem televisiva podem confundir-se entre si, mas nem sempre se correspondem.

\section{O controvertido papel do jornalismo da Rede Globo na redemocratização}

Nas diversas situações referidas, sobretudo a cobertura das "Diretas já", praticou-se um jornalismo movido pela autocensura; o temor à perda da concessão da rede televisiva condicionou abertamente os rumos do jornalismo. A sintonia, ora com os militares, ora com governos civis representantes das elites, foi tornando-se característica, chegando a ser referida em inúmeras críticas, por seu 'governismo' (BUCCI, 1996).

As opiniões e os posicionamentos políticopartidários dos proprietários da emissora dão o tom dos enfoques dados à editoria de política. No caso das "Diretas", a simpatia pela transição democrática lenta, gradual e restrita (alardeada pelos militares alinhados com o general presidente Figueiredo) chocava-se com o movimento popular por 'Diretas já'; portanto, esse deveria ser omitido ou focado discretamente. Na edição do debate Collor $\times$ Lula, a preferência pelo candidato do $\mathrm{PRN}$ alça-o ao patamar de melhor candidato e esse critério de escolha ganha status de verdade absoluta, colocando-se acima de qualquer critério imparcial; na campanha que pedia o impeachment de Collor, o jornalismo que, tradicionalmente, destacou-se pelos furos de reportagem e pela abordagem de fontes inéditas, permaneceu à sombra das emissoras de TV concorrentes e de outras modalidades midiáticas, pois, na época, Roberto Marinho ainda apoiava Collor (CONTI, 1999).

O tom emocional e a espetacularização dos acontecimentos e notícias, longe de representarem um mal ao jornalismo, aparecem em algumas situações como modelares. Assim, em mais de uma situação, a cena política é reduzida em metáforas que aludem ao futebol. É o caso do uso da expressão 'torcer', para explicar o que, supostamente, os defensores das "Diretas" já esperavam da Globo; é também o que se vê nas falas dos que julgam que a edição do debate Collor $\times$ Lula refletiu a verdade, ou seja, refletiu uma partida que teria sido desequilibrada, com o primeiro vencendo o segundo por 3 a 0 .

Destacam-se, ainda, algumas descontinuidades, ao compararem-se os depoimentos dos proprietários na época de cada um dos acontecimentos e o conjunto de textos ora apresentado pelas publicações do Memória Globo. Roberto Marinho, em 1990, tornou públicas algumas de suas concepções sobre o alcance de suas empresas, no que se refere 
ao poder do jornalismo. Em entrevista que concedeu pouco depois da eleição de Collor de Mello, o dono das Organizações Globo, embora não manifestasse esforços em demonstrarindependência dos governos civis que se sucederam - ao contrário, revelava até mesmo certa arrogância, ostentando o seu poder de influência nos rumos do país -, foi cauteloso ao responder sobre se usava seu poder e o que achava melhor para o Brasil. Respondeu enfatizando sua colaboração ao País:

[...] eu só useio poder nesse terreno opinativo no 'Globo'; em declarações e discursos eu uso essa colaboração - que eu considero modesta para o país. Você vê que a Rede Globo não é política, embora os jornais da Rede Globo tenham uma repercussão muito grande e uma forma de opinar. Não opinar mostrando o melhor, opinar em favor de determinados indivíduos, mas na melhoria e no aprimoramento e engrandecimento do país (ECHEVERRIA, 1990).

Note-se a ênfase na afirmação de que, no que se refere à Rede Globo, não se pretendia atuar em favor de determinados indivíduos, mas mostrar o que era melhor para o País. Em suma: exercer jornalismo abertamente opinativo, porém, supostamente apoiado nas regras do jogo democrático, de forma ampla e independentemente de performance momentânea de um candidato num debate. Contudo, o que se destaca nas afirmações de João Roberto Marinho sobre a edição do debate de 1989 é a justificativa de que Collor tinha ido melhor no debate, portanto, a edição jornalística deveria apontá-lo como vencedor. Cremos, então, que o afirmado pelo patriarca não teve efeito no critério de edição e/ou não influenciou as concepções do filho. Aqui, o mecanismo de parcialidade descola-se do opinativo e encontra, abertamente, o campo da manipulação.

\section{A perspectiva publicitária e despolitizante dos conteúdos veiculados pelo Memória Globo}

No que se refere às "Diretas", muito da polêmica estabelecida se deu em torno da 'confusão' entre festa de aniversário da capital paulista e manifestações políticas pelas eleições diretas na Praça da
Sé, em 25 de janeiro de 1984. O texto publicado a respeito pelo Projeto Memória Globo possui força, é convincente, principalmente porque, ao divulgar a íntegra da matéria que foi ao ar no dia do importante comício, deixa entrever que, a despeito da escalada em que era omitido completamente o comício - estava presente na notícia a natureza política do evento. No entanto, chama atenção a necessidade dos autores do texto em justificar a fusão entre aniversário e comício. Do ponto de vista do jornalismo, a hierarquia de importância dos dois eventos é clara: o comício era o acontecimento mais relevante no momento, no País, pela dimensão política e pela repercussão popular que vinha tendo. É fato que a data especial favorecia e tornava emblemática a manifestação política. Mas é indefensável, jornalisticamente falando, que se misturem as duas notícias tal como se fez na fatídica edição do Jornal Nacional.

Não se pode dizer, a rigor, que os depoimentos que as publicações do Projeto Memória Globo trazem à tona sejam mentirosos. Mas eles distorcem a realidade. Nos diversos exemplos que procuramos debater (das "Diretas Já", da edição do debate entre presidenciáveis e sobre o afastamento de Collor da presidência), ao recontar o ocorrido, as publicações do Projeto Memória Globo descontextualizam e tentam tornar factual e episódico algo que foi característico na atuação da emissora ao longo das décadas: a forte presença da opinião dos proprietários da emissora nas edições jornalísticas, imprimindo-lhes um tom invariavelmente conservador. Os fatos aparecem isolados da respectiva esfera histórica que os envolvia; tratados como se fossem meros fenômenos ligados a técnicas de reportagem ou de edição, os acontecimentos e suas implicações imediatas têm importância reduzida. E passam, no máximo, para o terreno dos erros individuais ou cotidianos. Porém, ao se recorrer às situações específicas em que ocorreram, verifica-se que, ao serem revisitados e recontados na forma de memória do telejornalismo, os episódios receberam grosseira despolitização. Há uma estratégia discursiva que os descola dos processos políticos em que se inseriam, relativizando o caráter manipulador que a edição jornalística pode engendrar.

Ainda do ponto de vista das práticas jornalísticas, nas situações analisadas nota-se que a versão atual da emissora, em comparação ao que fora declarado à época dos respectivos acontecimentos, é mais autocomplacente. O que se admitia, 
em alguma medida, como possível equívoco, por temor à ditadura, agora aparece como reafirmação de qualidade jornalística; como sinônimo de suposta imparcialidade.

\section{CONSIDERAÇÕES FINAIS}

Atualmente, ampliaram-se as preocupações da Rede Globo com a paulatina perda de pontos de audiência no chamado horário nobre (que envolve o Jornal Nacional). As preocupações com a imagem se intensificaram na última década e é recorrente o discurso relacionado aos governos militares, buscando demonstrar independência e exibir os supostos prejuízos sofridos com a censura (FANTINATTI, 2005). A emissora talvez já não possa deixar de se posicionar claramente, defendendo sua imagem, quando necessário, diante de críticas que ameacem a sua credibilidade.

Ocorre que, ao mencionar fatos que motivaram críticas no passado - às quais ela talvez não tenha respondido imediatamente - ela o faz sob o peso das distorções dos fatos que procura evidenciar. Torna-se necessário lembrar que, para grande parte do seu público e/ou leitor das obras do Projeto Memória Globo, muitos desses acontecimentos históricos são pouco explorados e conhecidos. Assim, cabe reiterar o clima político da fase final da ditadura militar e início da Nova República, para esclarecer o papel desempenhado pela Globo. Deixar de mostrar ao público as mobilizações de 1984 pelas "Diretas Já" relaciona-se harmônica e diretamente aos compromissos recíprocos entre a Globo com os governos militares, no poder na época. Do mesmo modo, a edição do debate de 1989, que antecipava a vitória de Collor, foi apenas corolário da preferência dos proprietários da Globo por aquela candidatura, e do seu temor a que partidos de esquerda se aproximassem do poder. Esses fatos traduziram coerentemente, cada um a seu tempo, as efetivas relações que a Globo mantinha com os respectivos setores antipopulares envolvidos: sintonizada tanto com os militares contra as eleições diretas, no primeiro caso, quanto com as elites que apoiavam a candidatura de Collor, no segundo. A despeito de qualquer livro de história sob encomenda que se publique, em qualquer época.

\section{REFERENNCIAS}

BIAL, P. Roberto Marinho. Rio de Janeiro: Jorge Zahar, 2004.

BONNER, W. Jornal Nacional: modo de fazer. Rio de Janeiro: Globo, 2009.

BUCCI, E. Brasil em tempo de TV. São Paulo: Boitempo, 1996.

CONTI, M. S. Notícias do Planalto. São Paulo: Companhia das Letras, 1999.

COTES, C.; KYRILLOS, L.; FEIJÓ, D. Voz e corpo na TV: a fonoaudiologia a serviço da comunicação. São Paulo: Globo, 2003.

DEBATE ENTRE CANDIDATOS À PRESIDÊNCIA. 1989. Disponível em: $<$ http://www.memoriaglobo.globo. com/Memoriaglobo/0,27723,5274,00.html>. Acesso em: 21 jun. 2009.

ECHEVERRIA, R. Entrevista - Roberto Marinho. O Estado de S. Paulo, São Paulo, 5 maio. 1990. Caderno 2, p. 4-5.

FANTINATTI, M. M. C. M. A nova Rede Globo: trabalhadores e movimentos sociais nas telenovelas de Benedito Ruy Barbosa. 2004. 340 f. Tese (Doutorado em Ciências Sociais) - Instituto de Filosofia e Ciências Humanas, Campinas, 2004.

. Comunicação de massa e poder político: o atual discurso da Rede Globo revelando seu empenho por uma nova imagem. In: BEZZON, L. (Org.). Comunicação, política e sociedade. Campinas: Alínea, 2005.

Jornal Nacional: a notícia faz história. Rio de Janeiro: Jorge Zahar, 2004.

HALL, S. Encoding and decoding in television discourse. In: HALL, S. et al. (Ed.). Culture, media, language. London: Hutchinson, 1980.

A identidade cultural na Pós-Modernidade. Rio de Janeiro: DP\&A, 1997.

KAMEL, A. A Globo não fez campanha; fez bom jornalismo. O Globo, 24 set. 2003.

MARTÍN-BARBERO, J.; REY, G. Os exercícios do ver: hegemonia audiovisual e ficção televisiva. São Paulo: Ed. SENAC, 2001. 
MEMÓRIA DE ROBERTO MARINHO. Revista

Recebido: 27/07/2009

Época, Rio de Janeiro, n. 273, 11 ago. 2003. Disponível

Received: 07/27/2009

em: <http://revistaepoca.globo.com/Época>. Acesso em: 27. jun. 2009.

Aprovado: 18/10/2009

PADIGLIONE, C. Caso diretas já foi 'censura dupla', Approved: 10/18/2009 diz Boni. Agência Estado, 30 dez. 2005. Disponível em: $<$ www.agenciaestado.com.br>. Acesso em:27. jun. 2009.

Revisado: 08/01/2009

PATERNOSTRO, V. Í. O texto na TV: manual de teleReviewed: 01/08/2009 jornalismo. Rio de Janeiro: Campus, 1999.

STOREY, J. Cultural theory and popular culture. Athens: The University of Georgia Press, 1993. 